\title{
Probiotics Regulating Inflammation via NLRP3 Inflammasome Modulation: A Potential Therapeutic Approach for COVID-19
}

\author{
Arezina N. Kasti ${ }^{1}$, Kalliopi D. Synodinou ${ }^{1}$, Ioannis A. Pyrousis ${ }^{1,2}{ }^{(0}$, Maroulla D. Nikolaki ${ }^{1}(\mathbb{D}$ \\ and Konstantinos D. Triantafyllou ${ }^{3, *(\mathbb{D})}$ \\ 1 Department of Nutrition and Dietetics, Attikon University General Hospital, 12462 Athens, Greece; \\ kastiare@med.uoa.gr (A.N.K.); kall.synodinou@gmail.com (K.D.S.); ipyrousis@gmail.com (I.A.P.); \\ maroullanikolaki@gmail.com (M.D.N.) \\ 2 Medical School, University of Patras, 26504 Patras, Greece \\ 3 Hepatogastroenterology Unit, 2nd Department of Propaedeutic Internal Medicine, Medical School, National \\ and Kapodistrian University of Athens, Attikon University General Hospital, 12462 Athens, Greece \\ * Correspondence: ktriant@med.uoa.gr; Tel.: +30-21-0583-2087
}

\section{check for} updates

Citation: Kasti, A.N.; Synodinou, K.D.; Pyrousis, I.A.; Nikolaki, M.D.; Triantafyllou, K.D. Probiotics Regulating Inflammation via NLRP3 Inflammasome Modulation: A Potential Therapeutic Approach for COVID-19. Microorganisms 2021, 9 , 2376. https://doi.org/10.3390/ microorganisms 9112376

Academic Editor: Sofia

Costa-de-Oliveira

Received: 3 October 2021

Accepted: 11 November 2021

Published: 17 November 2021

Publisher's Note: MDPI stays neutral with regard to jurisdictional claims in published maps and institutional affiliations.

Copyright: (c) 2021 by the authors. Licensee MDPI, Basel, Switzerland. This article is an open access article distributed under the terms and conditions of the Creative Commons Attribution (CC BY) license (https:/ / creativecommons.org/licenses/by/ $4.0 /)$.

\begin{abstract}
Inflammasomes are cytoplasmic multiprotein complexes formed by the host's immune system as a response to microbial infection and cellular damage. Many studies have revealed various regulators of NOD-, LRR-, and pyrin domain-containing protein 3 (NLRP3) inflammasome activation, while it has been recently shown that NLRP3 is implicated in COVID-19 pathogenesis. At the same time, probiotics counteract the inflammatory process and modulate cytokine release, thus influencing both innate and adaptive immune systems. Herein, we review the immunomodulatory potential of probiotics on the assembly of NLRP3 inflammasome, as well as the pathophysiological mechanisms supporting the use of probiotic bacteria for SARS-CoV-2 infection management, presenting evidence from preclinical studies of the last decade: in vivo, ex vivo, and mixed trials. Data show that probiotics intake is related to NLRP3 inflammasome attenuation and lower levels of inflammation markers, highlighting the beneficial effects of probiotics on inflammatory conditions. Currently, none of the ongoing clinical trials evaluating the effectiveness of probiotics intake in humans with COVID-19 has been completed. However, evidence from preclinical studies indicates that probiotics may block virus invasion and replication through their metabolites, bacteriocins, and their ability to block Angiotensin-Converting Enzyme 2 (ACE2), and by stimulating the immune response through NLRP3 inflammasome regulation. In this review, the beneficial effects of probiotics in the inflammatory process through NLRP3 inflammasome attenuation are presented. Furthermore, probiotics may target SARS-CoV-2 both by blocking virus invasion and replication and by stimulating the immune response through NLRP3 inflammasome regulation. Heterogeneity of the results-due to, among others, different bacterial strains and their metabolites, forms, dosage, and experimental designs-indicates the need for more extensive research.
\end{abstract}

Keywords: probiotics; inflammasomes; NLRP3 activation; mammalians; SARS-CoV-2

\section{Introduction}

Viral infection triggers host innate immune responses indicated by cytokine production and inflammasome activation [1]. Inflammasomes are cytoplasmic multiprotein complexes which consist of a sensor protein, the adaptor molecule apoptosis-associated speck-like protein containing a caspase recruitment domain (ASC), and the effector protein caspase-1. Active caspase- 1 proceeds to cleave the precursors pro-interleukin (IL)-1 $\beta$ and pro-IL-18 into mature forms IL-1 $\beta$ and IL-18, respectively, inducing pyroptosis. Inflammasomes are vital for the maintenance of intestinal homeostasis and gut-associated physiological inflammatory responses in humans. The NLRP3 (NLR family pyrin domain containing 3) inflammasome is assembled in both gut immune and epithelial cells [2] and it is the most widely studied inflammasome. 
Probiotic bacteria (PB) are live microorganisms that, when administered in adequate amounts, confer a health benefit on the host [3,4]. Lactobacilli and Bifidobacteria are the most common probiotics, but the yeast Saccharomyces boulardii and Bacillus species are also widely known [4]. PB — generally regarded as safe (GRAS) — have beneficial effects in various clinical conditions, such as the prevention of antibiotic-associated diarrhea, constipation, necrotizing enterocolitis, sepsis, and allergies in infants, while recently have shown promising results in oral health and periodontal therapy [5-11]. Lactic acid bacteria (LAB) can prevent gastrointestinal dysbiosis and reduce the risk of developing secondary infections, while other strains and their metabolites exhibit antiviral activities [12,13], such as enhancement of the barrier function by stimulating mucin secretion, antimicrobial activity by competing with microbial pathogens for nutrients and adhesion to epithelial cells producing antimicrobial substances such as bacteriocins and stimulation of mucosal epithelial cells to secrete defensins. Moreover, PB have immunomodulatory activity by interacting with dendritic cells (DCs), monocytes, and lymphocytes (Figure 1) [14].

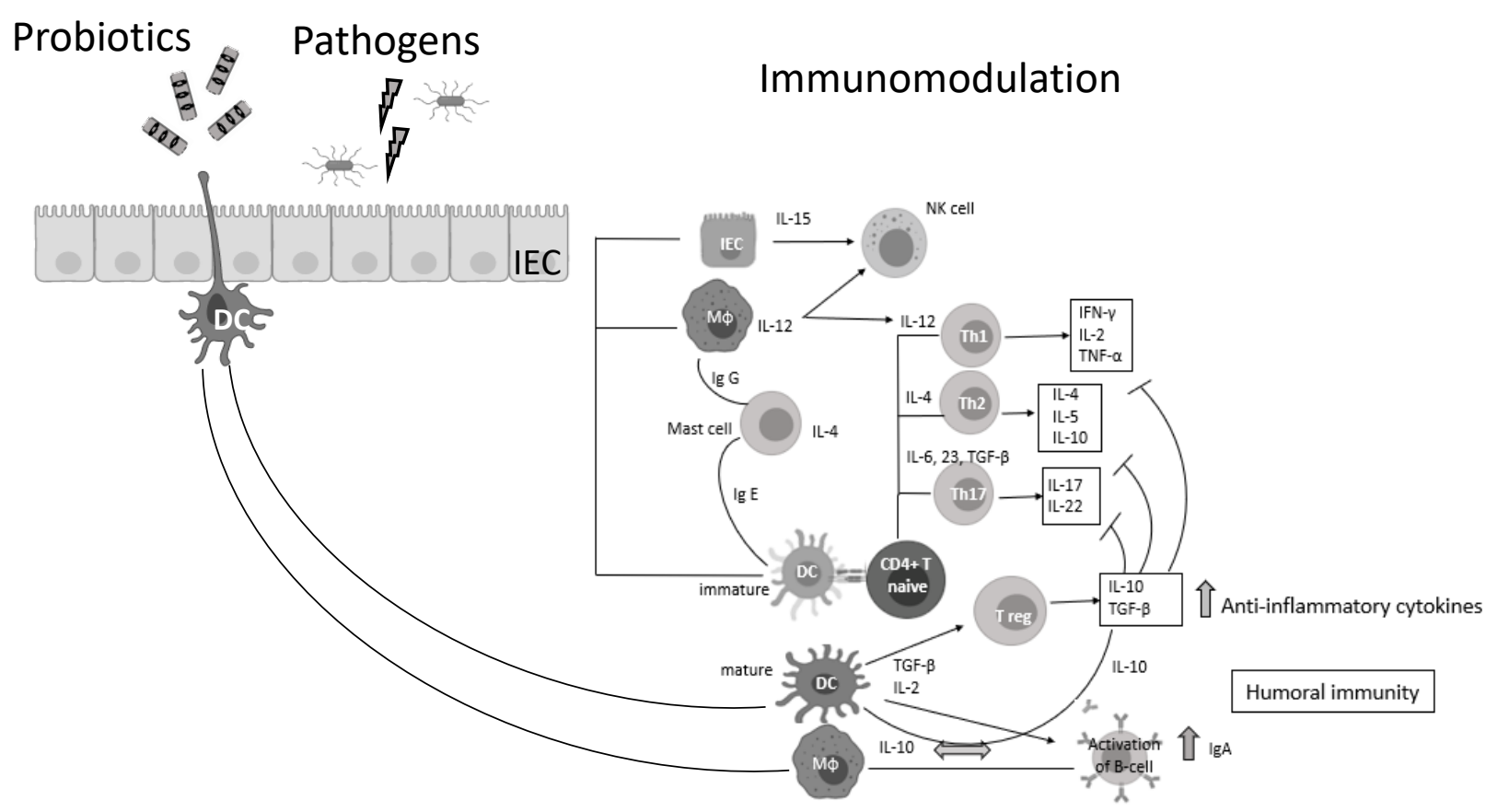

Figure 1. Probiotic bacteria can modulate cytokine release, thus influencing both innate and adaptive immune response. Part of this figure was created with BioRender (https:/ / biorender.com, accessed on 2 October 2021).

It is well documented that $\mathrm{PB}$ can regulate inflammation in two ways: (1) indirectly, by producing short-chain fatty acids (SCFAs) and (2) directly, by binding to innate immune system receptors Toll-like (membrane glycoproteins TLR 2, 4, 9) and by triggering important signaling pathways. One of these pathways includes the transcription factor NF- $\mathrm{kB}$, which is associated with the activation of NOD-like receptors (nucleotide-binding oligomerization domain-like receptors), that affect the formation of inflammasomes, thus the inflammatory response [15]. Overactivation of NLRP3 inflammasome has been linked to the pathogenesis of inflammatory bowel disease, cryopyrin-associated periodic syndromes, type 2 diabetes mellitus, atherosclerosis, and neurodegenerative diseases [16]. PB interact with the host by germline-encoded host sensors, namely, pattern recognition receptors (PRRs) [17], that detect microbial structures-pathogen-associated molecular patterns (PAMPs) and components of the host's cells released during cell damage or death named damageassociated molecular patterns (DAMPs) $[18,19]$. PRRs are expressed by most innate immune effector cells (dendritic cells, macrophages, monocytes, neutrophils, and epithelial cells). The mechanism of triggering the immune response depends on the kind of antigenic molecule [20]. Many recent studies focus on the complex mechanisms of NLRP3 activation 
stemming from pathogenic bacteria and their products, such as extracellular ATP and pore-forming toxins (Figure 2).

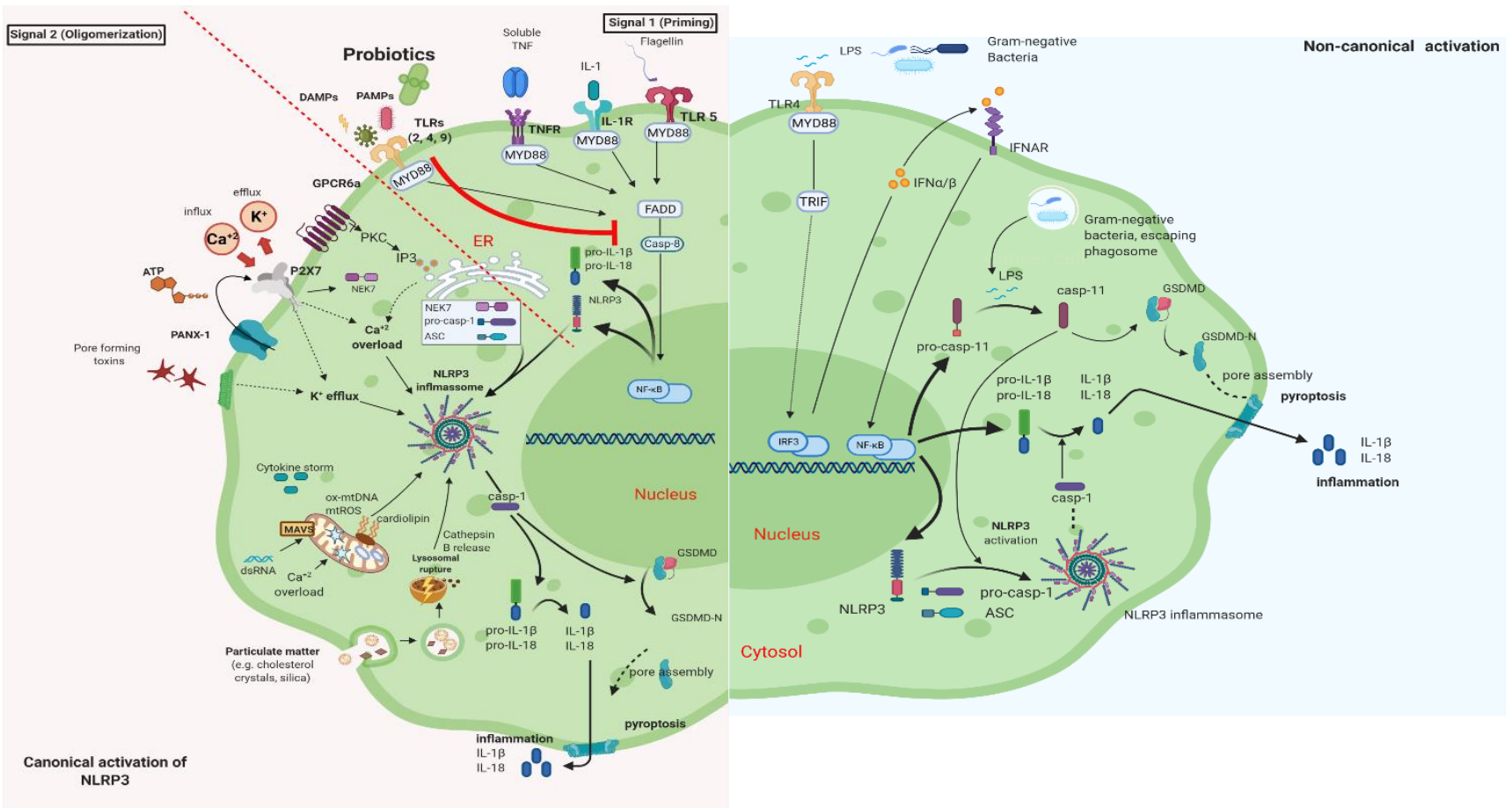

Figure 2. Canonical and Non-Canonical activation of NLRP3 inflammasome. The macrophage in an animal model (transgenic mice-expressing the human angiotensin I-converting enzyme 2 (ACE2) receptor driven by the cytokeratin-18 (K18) gene promoter (K18-hACE2)) [21,22]. (i) The canonical pathway of NLRP3 requires a two-step process: priming and activation. Priming (signal 1) is the upregulation of the NLRP3 inflammasome components, NLRP3, pro-IL $\beta$, and procaspase. This transcriptional upregulation is stimulated by PAMPs (bacterial, fungal, viral) or DAMPs which are recognized by PRRs such as TLRs. Additionally, cytokines such as TNF or IL-1 stimulate this upregulation by engaging TNFR and IL1-R, respectively. The activation (signal 2) is provided by various stress signals such as ion or plasma perturbations, ATP, lysosomal rupture, particulate matter, mitochondrial antiviral-signaling protein, mitochondrial reactive oxygen species, ox-mtDNA, etc. Oligomerization of NLRP3 inflammasome activates caspase-1, which in turn cleaves pro-IL $\beta$, pro-IL18, and GSDMD and induces pyroptosis and inflammation [23]. (ii) Gram-negative bacteria (e.g., lipopolysaccharide (LPS) or outer membrane vesicle from bacteria) can activate the non-canonical inflammasome pathway that involves NLRP3-dependent caspase-4/5 in humans (known as caspase-11 in murine models) [24]. Caspase-11, when it is secreted at normal rates, protects against bacterial infections, but its excessive activation can cause tissue damage and pyroptosis which is activated in both pathways through cytosolic gasdermin (GSDMD), a member of the gasdermin family [25]. GSDMD cleavage generates a N-terminal domain that is capable of forming plasma membrane pores and a C-terminal domain that acts as an inhibitor of cytolysis [26]. The cleaved N-terminal domain of GSDMD oligomerizes and forms pores on the host cell membrane, leading to pyroptosis and further activation of NLRP3 by triggering $\mathrm{K}^{+}$efflux $[27,28]$. This figure was created with BioRender (https:/ / biorender.com, accessed on 2 October 2021).

In this review, we aim to investigate the impact PB have on stimulating the assembly of NLRP3 inflammasome, as well as the pathophysiological mechanisms supporting the use of PB in COVID-19.

We assessed preclinical studies focusing on the activation of NLRP3 by PB during the decade 2010-2020. A literature research using the terms "probiotics", "inflammasome" and "NLRP3" and their combination in PubMed and Cochrane databases revealed twenty-two publications in English language. We used evidence from the original articles only and we included studies identified by manual search of the reference lists of the aforementioned articles. Similarly, we assessed the available literature in PubMed and Cochrane databases and in ClinicalTrials.gov (accessed on 3 December 2020) using the terms "NLRP3, 
COVID-19, probiotics" "SARS-CoV-2", and their combination on the use of probiotics as immunomodulators of COVID-19 infection management through NLRP3 inflammasome manipulation.

\section{Probiotic Bacteria and NLRP3 Activation}

We did not detect any publication investigating the role of PB on NLRP3 inflammasome activation in humans in vivo. A total of fifteen studies (in vivo, ex vivo) providing data regarding the NLRP3 inflammasome stimulation by PBs in a variety of cellular and animal models were included in this review. More specifically, four studies on mammals (three porcine, one canine), seven on laboratory animals (four rats, three mice), one on rodents (Syrian hamsters), and three on cell cultures, in which inflammatory biomarkers were measured. Treatment included probiotic supplements (regardless of viability, strains, forms, dosages, and duration of treatment). The effect of probiotics on alterations in inflammation markers (IL-1 $\beta$, TNF-a, IL-6, IL-18) and any immunomodulatory potential related to intervention were considered as endpoints.

Heterogeneity was the main feature of the included studies. Different types of trials, interventions, subjects, and cell cultures and a variety of PB strains and metabolites, dosages, and duration precluded adequate studies classification (Table 1, Table S1).

Table 1. Trials (in vivo, ex vivo) with probiotic administration and NLRP3 activation in animals and cell cultures.

\begin{tabular}{|c|c|c|c|c|}
\hline $\begin{array}{c}\text { Author, Year of } \\
\text { Publication }\end{array}$ & Subjects & Treatment & NLRP3 & $\begin{array}{c}\text { Mechanism of the Antiviral } \\
\text { Activity }\end{array}$ \\
\hline $\begin{array}{l}\text { Schmitz S. et al., } \\
2015 \text { (in vivo) }\end{array}$ & \multirow[b]{2}{*}{ Canine } & \multirow[b]{2}{*}{$1 \times 10^{7} \mathrm{CFU}$ Enterococcus faecium } & \multirow[b]{2}{*}{ Suppression } & $\begin{array}{l}\text { Reduction of the expression of } \\
\text { mRNA transcripts for NLRP3 }\end{array}$ \\
\hline (ex vivo) [29] & & & & $\begin{array}{c}\text { No significant difference in } \\
\text { mRNA expression of NLRP3 and } \\
\text { IL-1 } \beta\end{array}$ \\
\hline $\begin{array}{l}\text { Avolio et al., } 2018 \\
\quad \text { (in vivo) [30] }\end{array}$ & Syrian Hamsters & $\begin{array}{c}\text { Mix of probiotics, } 3 \mathrm{~g} \text { of which } \\
\text { contained: } \\
1.5 \times 10^{10} \mathrm{CFU} \text { Streptococcus } \\
\text { thermophilus } \\
1.5 \times 10^{10} \mathrm{CFU} \text { Lactobacillus } \\
\text { bulgaricus } \\
1.5 \times 10^{10} \mathrm{CFU} \text { Lactococcus lactis } \\
\text { subsp. lactis } \\
1.5 \times 10^{10} \mathrm{CFU} \text { Lactobacillus } \\
\text { acidophilus } \\
1.5 \times 10^{10} \mathrm{CFU} \text { Streptococcus } \\
\text { thermophiles } \\
1.5 \times 10^{10} \mathrm{CFU} \text { Lactobacillus } \\
\text { plantarum } \\
1.5 \times 10^{10} \mathrm{CFU} \text { Bifidobacterium } \\
\text { lactis } \\
1.5 \times 10^{10} \mathrm{CFU} \text { Lactobacillus } \\
\text { reuteri }\end{array}$ & Suppression & $\begin{array}{c}\text { Decrease in expression levels of } \\
\text { NLRP3 in hypothalamus, along } \\
\text { with the circulating levels in } \\
\text { blood }\end{array}$ \\
\hline $\begin{array}{l}\text { Teixeira et al., } 2018 \\
\quad \text { (in vivo) [31] }\end{array}$ & Rats & $1 \times 10^{8}$ CFU L. johnsonii N6.2 & Suppression & $\begin{array}{l}\text { Reduction in caspase- }-1 \\
\text { expression and maturation }\end{array}$ \\
\hline $\begin{array}{l}\text { Ding et al., } 2019 \\
\text { (in vivo) [4] }\end{array}$ & Rats & $\begin{array}{c}1 \times 10^{9} \mathrm{CFU} / \mathrm{ml} \text { Lactobacillus } \\
\text { rhamnosus GG }\end{array}$ & Suppression & $\begin{array}{l}\text { Reduction in mRNA and protein } \\
\text { levels of pro-inflammatory } \\
\text { cytokines IL-1 } \beta, \text { NLRP3, TNF-a, } \\
\text { and IL-6 in the liver }\end{array}$ \\
\hline $\begin{array}{l}\text { Wu et al., } 2016 \\
\text { (ex vivo) [32] }\end{array}$ & Bovine & $\begin{array}{c}3 \times 10^{7} \text { CFU Lactobacillus } \\
\text { rhamnosus }\end{array}$ & Suppression & $\begin{array}{l}\text { Decrease of the production of } \\
\text { IL-8, IL-6, and TNF-a associated } \\
\text { with synergistic responses of } \\
\text { TLR-, NLR-, and } \\
\text { NLRP3-mediated signaling }\end{array}$ \\
\hline
\end{tabular}


Table 1. Cont.

\begin{tabular}{|c|c|c|c|c|}
\hline $\begin{array}{l}\text { Author, Year of } \\
\text { Publication }\end{array}$ & Subjects & Treatment & NLRP3 & $\begin{array}{c}\text { Mechanism of the Antiviral } \\
\text { Activity }\end{array}$ \\
\hline $\begin{array}{l}\text { Xia et al., } 2020 \\
\text { (in vivo) [33] }\end{array}$ & Porcine & $\begin{array}{c}1 \times 10^{9} \mathrm{CFU} / \mathrm{mL}, 10 \mathrm{~mL} / \text { day } \\
\text { Lactobacillus johnsonii L531 }\end{array}$ & Suppression & $\begin{array}{l}\text { Suppression of inflammasome } \\
\text { activation through the } \\
\text { elimination of damaged } \\
\text { mitochondria and accelerated } \\
\text { autophagic degradation }\end{array}$ \\
\hline $\begin{array}{l}\text { Loss et al., } 2018 \\
\text { (ex vivo) [34] }\end{array}$ & Porcine & Enterococcus faecium & $\begin{array}{l}\text { Non } \\
\text { activation }\end{array}$ & $\begin{array}{l}\text { E. faecium does not influence or } \\
\text { only minimally affects the } \\
\text { NLRP3 inflammasome pathway }\end{array}$ \\
\hline $\begin{array}{l}\text { Li et al., } 2018 \\
\text { (in vivo) [35] }\end{array}$ & Porcine & $\begin{array}{c}3 \times 10^{8} \text { CFU Clostridium } \\
\text { butyricum }\end{array}$ & $\begin{array}{l}\text { Non } \\
\text { activation }\end{array}$ & $\begin{array}{c}\text { Inhibition of the } \\
\text { ASC-independent NLRP3 } \\
\text { inflammasome signaling } \\
\text { pathway }\end{array}$ \\
\hline $\begin{array}{l}\text { Chung et al., } 2019 \\
\text { (in vivo) [36] }\end{array}$ & Mice & $\begin{array}{c}17 \mathrm{mg} / \mathrm{kg} \text { Enterococcus faecalis } \\
\mathrm{KH} 2\end{array}$ & Suppression & $\begin{array}{c}\text { Attenuation of bacteria-Induced } \\
\text { NLRP3 activation by decreasing } \\
\text { bacterial phagocytosis }\end{array}$ \\
\hline $\begin{array}{l}\text { Luo et al., } 2019 \\
\text { (in vivo) [37] }\end{array}$ & Rats & $\begin{array}{l}\text { microbe-derived antioxidant } \\
\text { (MA) } \\
\text { (fermented by Bacillus subtilis, } \\
\text { Lactobacillus, Beer yeast) }\end{array}$ & Suppression & $\begin{array}{l}\text { MA decreased gene expression } \\
\text { of NLRP3, IL-1 } \beta \text {, and IL-18 }\end{array}$ \\
\hline $\begin{array}{l}\text { Tohno et al., } 2011 \\
\text { (ex vivo) [38] }\end{array}$ & Porcine & $\begin{array}{c}\text { Lactobacillus delbrueckii subsp. } \\
\text { bulgaricus and Lactobacillus } \\
\text { gasseri }\end{array}$ & $\begin{array}{l}\text { Appropriate } \\
\text { activation }\end{array}$ & $\begin{array}{l}\text { Lactobacillus strains promote the } \\
\text { NLRP3 expression via TLR and } \\
\text { NOD-mediated signaling, } \\
\text { inducing of appropriate NLRP3 } \\
\text { activation }\end{array}$ \\
\hline $\begin{array}{l}\text { Bai et al., } 2020 \\
\text { (in vivo) [39] }\end{array}$ & Mice & $\begin{array}{l}\text { Bacteriocins produced by } \\
\text { L. helveticus: PJ4, L. brevis: DT24 } \\
\text { and L. animalis: TSU4 }\end{array}$ & Suppresion & $\begin{array}{l}\text { Reduction in TNF-a, IL-1 } \beta \text {, IL-6 } \\
\text { because of PJ4 supplementation }\end{array}$ \\
\hline $\begin{array}{l}\text { Fan et al., } 2019 \\
\text { (in vivo) [40] }\end{array}$ & Rats & Bacteroides fragilis ZY-312 & Suppresion & $\begin{array}{l}\text { Reduction in NLRP3, caspase-1, } \\
\text { IL-1 } \beta \text {, and GSDMD }\end{array}$ \\
\hline $\begin{array}{l}\text { Wu et al., } 2020 \\
\text { (in vivo) [41] }\end{array}$ & Mice & Roseburia intestinalis & Suppresion & $\begin{array}{l}\text { Reduction in NLRP3 activation, } \\
\text { caspase -1, GSDMD, and } \\
\text { pyroptosis in THP-1 } \\
\text { macrophages. }\end{array}$ \\
\hline $\begin{array}{l}\text { Kern et al., } 2017 \\
\quad \text { (in vivo) }\end{array}$ & Porcine & Enterococcus faecium & No difference & $\begin{array}{l}\text { No difference in mRNA } \\
\text { expression of NLRP3, caspase-1, } \\
\text { IL-1 } \beta \text {, and IL-18 in the } \\
\text { duodenum and colon }\end{array}$ \\
\hline (ex vivo) [42]) & & & & $\begin{array}{l}\text { No significant difference in } \\
\text { NLRP3 expression }\end{array}$ \\
\hline
\end{tabular}

CFUs: colony forming units; GSDMD: gasdermin; ASC: apoptosis-associated speck-like protein; TLR: Toll-like receptor; TNF-a: tumor necrosis factor alpha.2.1. In Vivo Trials.

Pigs fed on either a basal diet or a Clostridium butyricum-supplemented diet were given orally enterotoxigenic Escherichia coli (ETEC) K88 or saline. The results of this Chinese study showed that $C$. butyricum decreased IL- $1 \beta$ and IL-18 levels in serum and gut tissue, whereas IL-10 levels were increased. C. butyricum promoted the accumulation of intestinal NLRP3 mRNA and inhibited ETEC K88-induced caspase-1 and NLRP3 increase [35]. In an Italian study that investigated behavioral and obesity effects in hamsters fed with high fat diet (HFD), IL-1 $\beta$, NLRP3, caspase-1, and NF-kB levels were measured in the presence or absence of a multispecies probiotic formulation. Hamsters were subjected to unpredictable chronic mild stress. Consequently, PB decreased hypothalamic expression and hematic circulating levels of all above inflammatory markers, while HFD increased 
them [30]. In a study published in 2020, three purified bacteriocins produced by L. helveticus: PJ4, L. brevis: DT24, and L. animalis: TSU4 were administered in mice as a treatment strategy for HFD induced obesity. Subjects were divided into five groups and all groups were fed with HFD-except for controls. Three HFD groups received three bacteriocins, respectively. Results showed that the inflammatory mediators (IL- $1 \beta$, IL-6, TNF- $\alpha$ ) were significantly increased in the HFD group without bacteriocins administration. The DT24 group did not show any change in cytokines levels, while PJ4 and TSU4 groups showed a significant reduction; PJ4 was more effective than TSU4 in decreasing inflammatory biomarkers. Notably, increased NLRP3 expression was observed in all groups, especially in HFD compared to controls [41]. University of Florida researchers evaluated the effects of Lactobacillus johnsonii N6.2 in combination with rosmarinic acid, a natural antioxidant with anti-inflammatory properties, on inflammasome assembly in ileal tissue of diabetes-prone rats. Their findings confirm that L. johnsonii suppresses NLRP3 and caspase-1 maturation lowering overall intestinal inflammation [31]. When the effect of oral preadministration of L. johnsonii L531 in piglets with Salmonella infantis-induced enteritis was evaluated, $S$. infantis activated NLRP3 and NF-KB signaling in the jejunum and ileal tissue, L. johnsonii L531 administration before the challenge reduced the severity of intestinal inflammation and prevented the excessive expression of NLRP3 and caspase- 1 through the elimination of damaged mitochondria and accelerated autophagic degradation [33]. Similarly, in rats with cecal ligation and puncture-induced sepsis, the administration of a different strain of Lactobacillus (L. rhamnosus GG, LGG) decreased IL-1 $\beta$, NLRP3, IL-6, and TNF-a levels in liver tissues indicating the anti-inflammatory role of LGG. Moreover, B. fragilis ZY-312 probiotic therapy reduced liver injury following experimental sepsis in neonatal rats with necrotizing enterocolitis (NEC) induced by Cronobacter sakazakii [4]. Fan et al. evaluated the effects of $C$. sakazakii on intestinal barrier function and the protective role of ZY-312. They showed that the expression of NLRP3, caspase-1 (p10, p20), IL-1, and gasdermin D were significantly increased in the $C$. sakazakii group. Meanwhile, ZY-312 ameliorated the deleterious effects of C. sakazakii on intestinal integrity and attenuated clinical symptoms (weight loss, loss of appetite, abdominal flatulence) and intestinal inflammation [40]. The anti-inflammatory effects of Roseburia intestinalis-derived flagellin (a subunit protein of the flagellum, a whip-like appendage that allows bacterial motility) have been investigated in a dextran sulfate sodium (DSS) induced colitis model in mice [43]. The mRNA levels of NLRP3 and IL $1 \beta$ were upregulated in the DSS group compared with the control group, but treatment with probiotic Roseburia intestinalis flagellin remarkably alleviated the intestinal inflammation inhibiting the increase of proinflammatory cytokines (IL $1 \beta$, IL 18, IL 6, and TNF $\alpha$ ) levels in serum and decreasing the NLRP3 activation in colonic tissues.

Chung et al. [36]. assessed the immunomodulatory effects of heat-killed Enterococcus faecalis, a commensal $\mathrm{Gram}^{+}$lactic acid bacterium, and its potential protective role on intestinal inflammation in murine models of DSS-induced colitis and colitis-associated colorectal cancer. E. faecalis ameliorated the severity of inflammation and attenuated NLRP3 activation in THP-1-derived macrophages while inducing the expression of proand mature IL-1 $\beta$ but did not affect the amount of active caspase-1 [36]. In another detailed analysis, microbe-derived antioxidant (MA) fermented by Bacillus subtilis, Lactobacillus, and beer yeast was used in mother rats and offspring. MA supplementation attenuated HFD-induced NLRP3 activation in the liver and decreased IL-1 $\beta$ and IL-18 gene expression in HFD-induced hepatic lipid disorders during pregnancy and lactation and improved hepatic function [37].

\subsection{Ex Vivo Trials}

In 2011, investigators cloned and sequenced porcine NLRP3 cDNA isolated from ileal Peyer's patches. Then, they examined the expression of NLRP3 in diverse tissues (spleen, esophagus, duodenum, jejunum, ileum, Peyer's patches, colon, and mesenteric lymph nodes (MLNs) from newborn and adult porcine); they also examined the ability of two Lactobacilli strains (L. delbrueckii subsp. bulgaricus NIAI B6 and L. gasseri JCM1131T) 
to evoke the expression of NLRP3 in the gut-associated lymphoid tissues (GALT) of the subjects showing that the two strains of lactic acid bacteria can enhance NLRP3 expression in adult and newborn GALT [38]. Later, one different team investigated the potency of L. rhamnosus GR-1 to prevent E. coli adhesion and described the effects of L. rhamnosus GR-1 on ameliorating $E$. coli-induced mastitis and cell damage in primary bovine mammary epithelial cells (BMECs), as well as the NLRP3 inflammasome activation. They showed that NLRP3 expression and caspase-1 were increased during E. coli infection, while $L$. rhamnosus GR-1 pretreatment ameliorated E. coli-induced mastitis. Preincubation of BMECs with probiotic strains had no direct killing effect on $E$. coli but reduced the adhesion levels to about $50 \%$ of that observed in BMECs infected with E. coli. BMECs treated with $L$. rhamnosus GR-1 did not exhibit increased NLRP3 activation compared with untreated controls, whereas IL-6, IL-8, and TNF-a production was downregulated [32]. Treatment with probiotic Enterococcus faecium NCIMB 10415 (E. faecium) was examined in porcine monocyte-derived dendritic cells (MoDC) infected by ETEC to elicit NLRP3 inflammasome activation [34]. Inflammasome activation normally requires a two-step process (priming and activation) to induce its transcription; in this case, the research team studied the $E$. faecium potency on primed cells with LPS (mono- and co-incubated; $n=5$ independent experiments) and unprimed cells (mono- and co-incubated; $n=4$ independent experiments). In a co-incubation experiment, MoDC were pretreated with E. faecium for $1 \mathrm{~h}$ and then were challenged with ETEC for $1 \mathrm{~h}$ as well, as in the ETEC mono-incubation. The expression of NLRP3 components was measured in MoDC after 1.5, 6, and $20 \mathrm{~h}$ of stimulation. The complex design of the experiments showed that priming of MoDC with LPS for $3 \mathrm{~h}$ induced an increased mRNA expression of IL-1 $\beta$, IL-18, caspase-1, and NLRP3. In the unprimed cells, the mRNA expression of IL-1 $\beta$, IL-18, and NLRP3 was significantly increased in cultures incubated with ETEC, but at the 6th and 20th $\mathrm{h}$. The pathogenic ETEC strain stimulates a time-dependent inflammasome response, possibly because LPS is present in the outer membrane of ETEC, unlike the E. faecium that did not stimulate NLRP3.

\subsection{Mixed Trials}

In 2015, Schmitz et al. [29]. assessed the intestinal expression of caspase-1, IL-1 $\beta$, IL-18, and NLRP3 in canines with chronic enteropathy (CE) compared to controls when treated with E. faecium in vivo and ex vivo. In in vivo experiments, all groups were fed a standardized diet. Samples were collected from duodenal and colonic biopsies. Results showed that inflammasome-related genes in the duodenum were not significantly different between dogs with probiotic or placebo treatment, whilst they were expressed at a much higher level in the colon than in the duodenum (both in healthy and CE dogs). Interestingly, IL-1 $\beta$ protein expression in CE group was decreased with dietary treatment (not with PB). In ex vivo culture of duodenal biopsies (macrophage DH82 cells), the samples were stimulated with different TLR ligands and E. faecium. Incubation with E. faecium increased caspase-1 levels compared to stimulation with pure TLR ligands (PBS, Flagellin, Pam3CSK4, LPS), but did not affect the NLRP3 expression independently of disease status. Challenge with pure TLR ligands showed minor effects on mRNA levels of the NLRP3 components apart from IL-18 [29].

In another mixed trial, German scientists investigated the expression of NLRP3 components in sows and piglets' intestines (jejunal, ileal, and colonic tissues) and analyzed the influence of age and long-term supplementation with the E. faecium NCIMB 10,415 [42] on NLRP3 expression. NLRP3 expression in tissues was higher in 29-day-old piglets compared to 70-day-old growing pigs, indicating that age is a factor that affects NLRP3 inflammasome activation. Furthermore, they examined cell cultures (intestinal epithelial cells) which first were challenged with ETEC and then inoculated with E. faecium NCIMB 10415. Expression of NLRP3 was slightly higher in epithelia mono-incubated with E. faecium or ETEC compared with epithelia incubated with E. faecium and ETEC whereas IL-1 $\beta$ and IL-18 did not differ significantly between the treatment groups but tended to be higher in epithelia incubated with ETEC. 
To sum up, most of the above-mentioned trials showed NLRP3 attenuation and decreased levels of inflammation markers -caspase-1, IL-1 $\beta$, IL-6, IL-18, and TNF-a-after PB administration/incubation (Table 1). The age of the subjects, the exact time in which the samples were analyzed, and the condition of treatment or pretreatment of different pathogens and challenges are of concern in interpreting the results. Beneficial effects of PB seem to be affected by many factors, including different bacterial strains and their metabolites, forms (viable or nonviable3. Involvement of SARS-CoV-2 in NLRP3 Activation.

Although COVID-19 pathogenesis remains elusive, emerging evidence indicates the role of NLRP3 inflammasome involvement in its pathogenesis [44,45].

In humans, the main clinical manifestations of severe acute respiratory syndrome coronavirus 2 (SARS-CoV-2) infection are severe acute respiratory failure and macrophage activation syndrome (MAS) [46]. The immune response to SARS-CoV-2 is driven by inflammatory alveolar and monocyte-derived macrophages, which are activated by PAMPs and DAMPs, released by infected pneumocytes [47]. The massive release of cytokines, produced by the triggered innate immune system, leads to NLRP3 hyperactivation through viroporins. Viroporins are a group of viral proteins (protein E, open reading frame 3a (ORF3a), and ORF8a) with ion channel activity that takes part in virus replication and disease pathogenesis [48]. SARS-CoV-2 was confirmed to evoke gut inflammation in intestinal epithelial cells (IECs) and epithelial alveolar cells by invading in the same way. The virus invades the cells of the host through angiotensin-converting enzyme 2 (ACE2) receptors, expressed in both the respiratory and the GI tract. The viral protein S (Spike S glycoprotein) is activated by the transmembrane protease serine 2 (TMPRSS2) leading to the proinflammatory cytokine cascade. The downregulation of ACE2 caused by SAR-CoV-2 leads to alter gut microbiota, increased intestinal permeability, and inflammation directly linked to gastrointestinal symptoms and diarrhea in patients with COVID-19 [49-51].

It is already known that there is bidirectional crosstalk between gut and lung, named the gut-lung axis, which is involved in immune homeostasis. The underlying mechanism linking dysbiosis of gut microbiota with several respiratory diseases and dysbiosis of the lung microbiota is not fully understood. A potential mechanism could be the leaky gut and the migration of bacterial products or particles to the lung, stimulating the immune response. Additionally, blood or lymphatic mediated circulation of immune cells or inflammatory cytokines from the GI tract to the lung can induce inflammatory response [21]. The antiviral activity of probiotics against common respiratory viruses (including influenza, rhinovirus, and respiratory syncytial virus) is already confirmed by clinical and experimental studies [22,52]. LAB may offer protection from airway infection indirectly, through interaction with GALT, eliciting an enhancement of respiratory immunity. Furthermore, the protective role of probiotics is associated with the activation of proinflammatory natural killer (NK) cells and macrophages within the airway mucosa [53].

\section{The Antiviral Activity of Probiotic-Produced Metabolites}

PB, through the production of antimicrobial substances, such as bacteriocins (proteinaceous products), inhibit bacterial adherence and invasion capacity in the intestinal epithelium [54]. The inhibitory activity of bacteriocins includes effects against pathogens responsible for hospital-acquired infections and many Gram-negative bacteria. They can bind to the cell surface receptors and reduce the virus-induced cytopathic effects at a preincubation condition. Additionally, bacteriocins inhibit virus replication (Lactobacillus delbrueckii subsp. Bulgaricus 1043 bacteriocin inhibited the replication of influenza virus) blocking receptor sites on host cells and avoid the accumulation of viral particles $[14,47,55]$, as well. Enterocin CRL35, a bacteriocin produced by Enterococcus mundtii CRL35, has proven antiviral effects against strains of Herpes simplex viruses (HSV)-1 and HSV-2 by inhibiting late stages of replication in vitro [56]. Furthermore, probiotic Bacillus amyloliquefaciens produces another bacteriocin, subtilosin, with antiviral properties against HSV and influenza virus. In this context, bacteriocins may have antiviral action against SARS-CoV-2 [57]. 
Hydrogen peroxide $\left(\mathrm{H}_{2} \mathrm{O}_{2}\right)$ is a defense mechanism with natural microbicide action preventing contamination by microorganisms. $\mathrm{H}_{2} \mathrm{O}_{2}$ is a non-proteinaceous substance produced by several bacteria, and probiotics. More specifically, studies showed that Lactobacillus sp. in the vaginal cavity produces $\mathrm{H}_{2} \mathrm{O}_{2}$ with toxic effects on viruses like $\mathrm{HIV}$ and HSV-2. In vitro tests revealed that the amount of $\mathrm{H}_{2} \mathrm{O}_{2}$ was sufficient to inactivate $\mathrm{HIV}[13,58]$ and researchers concluded that $\mathrm{H}_{2} \mathrm{O}_{2}$ protect against a variety of viral pathogens and improve antigenicity and immunogenicity [59].

In this context, other metabolites produced by Lactobacillus plantarum showed effectiveness against transmissible gastroenteritis virus infection, a member of the family Coronaviridae. However, the evidence on mechanisms of action by which these probioticproduced metabolites exert their specific effects in certain systems or diseases has not yet been elucidated [59].

\subsection{Probiotics Targeting Angiotensin-Converting Enzyme}

In animal models experimentally infected with SARS-CoV-2, the protein sequence and structure of ACE2 are conserved across mammalians [60]. However, until now, there has been no published study in which NLRP3 activation was investigated following SARSCoV-2 infection in animals. LAB fractions (mainly belonging to Lactococcus lactis and Lactobacillus helveticus), in in vitro experiments, showed inhibitory activity towards ACE enzymes by blocking the active sites [24,25]. Moreover, the debris of the dead probiotic cells acts as ACE inhibitors too, suggesting that $\mathrm{PB}$ could be a potential blocker of $\mathrm{ACE}$ and ACE2 receptors which act as a gateway for SARS-CoV-2 to attack GI cells (Figure 3) [22,61]. Recently, another in vitro trial in this field has confirmed that Lactobacillus plantarum bacteriocins (Plantaricin W, D, and JLA-9) inhibit the entry of SARS-CoV-2 by blocking ACE2 receptors and virus transcription (targeting on the $S$ protein and blocking RNA polymerase (RdRp)) [21]

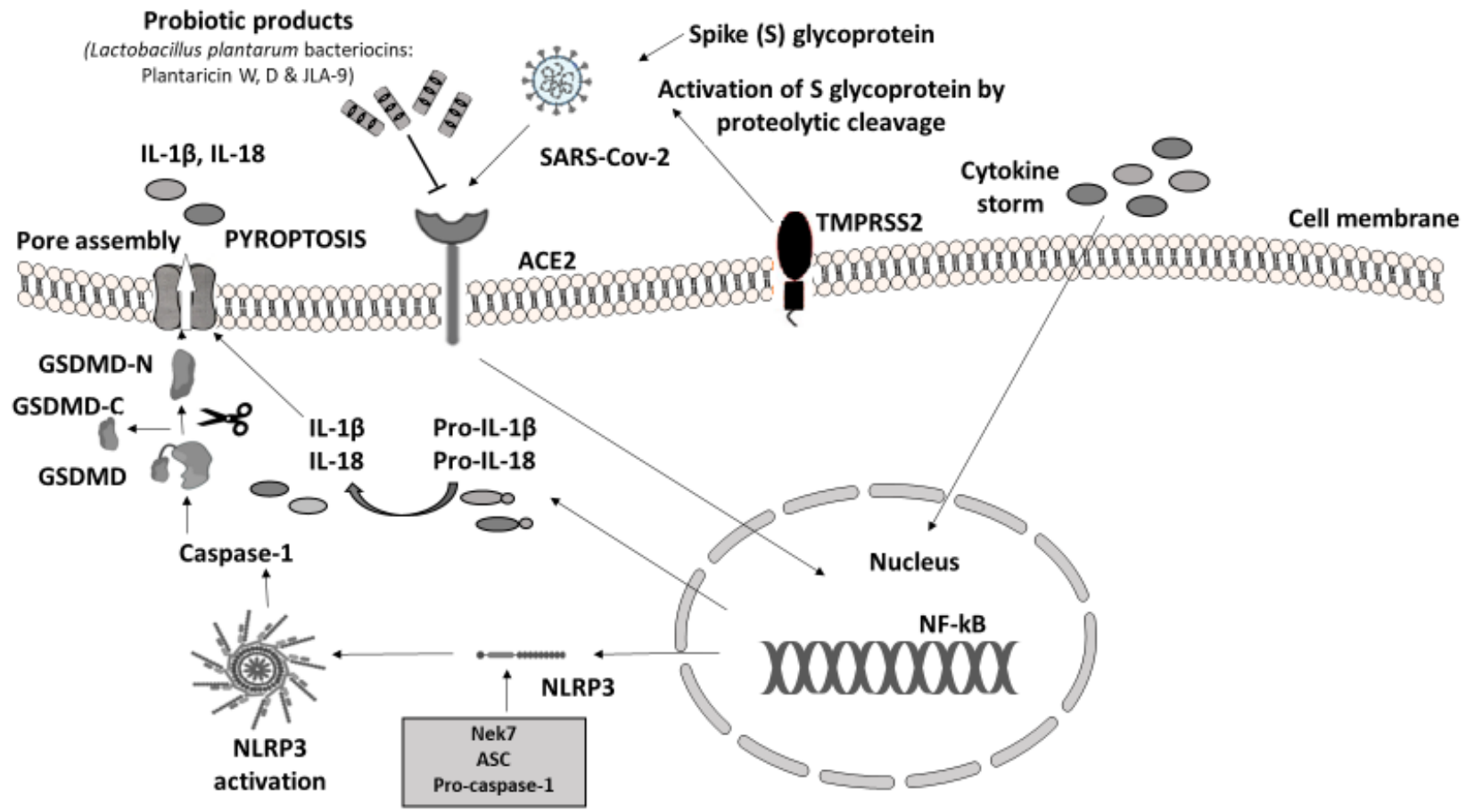

Figure 3. Probiotic bacteria products blocking ACE2 receptors may attenuate COVID-19 infection. Immune response to SARS-CoV-2. Virus invasion is carried out through ACE2 receptor and viral protein S (Spike S glycoprotein) is activated by TMPRSS2 leading to the proinflammatory cytokine cascade. The massive release of cytokines (IL-1 $\beta$, IL-2, IL-7, IL-8, $\mathrm{IFN} \gamma, \mathrm{TNF} \alpha, \mathrm{IP} 10$, etc.) from innate immune cells induces the activation of NF-kB signaling pathway that regulates the transcription of NLRP3 inflammasome-related components as well as pro-IL-1 $\beta$ and pro-IL-18. As soon as it is formed, NLRP3 inflammasome cleaves pro-caspase- 1 and converts it into its active form, caspase-1 [23,62,63]. Subsequently, caspase-1 
proceeds with the cleavage of inactive precursors pro-IL-1 $\beta$ and pro-IL-18 to their mature forms IL-1 $\beta$ and IL-18 respectively; at the same time GSDMD is cleaved by the same protease in two domains, an N-terminal and a C-terminal. Following the N-terminal fragment of GSDMD assembles pores in the plasma membrane, inducing pyroptosis and cell death [23]. Experimental studies have shown that SARS-CoV-2 cell entry could be potentially prevented through the antagonistic effect of specific probiotic strains. PB, except for their ability to inhibit the adhesion of pathogens in the intestinal epithelium, compete with pathogens for nutrients and produce antimicrobial substances (e.g., bacteriocins), providing immunomodulatory action and enhancing epithelial barrier function [64]. Their anti-inflammatory effect suppresses cytokine production. Additionally, SARS-CoV-2 evokes inflammation by infecting host cells through the ACE2 receptor and TMPRSS2 inducing proinflammatory cytokine release. Lactobacillus plantarum metabolic product (Plantaricin) blocks the entry of SARS-CoV-2 by binding with ACE2 [21,23,65-67]. Parts of this figure were created with BioRender (https://biorender.com, accessed on 2 October 2021) and MOTIFOLIO Download Free Sample (https:/ /www.motifolio.com/sampleslides.html, accessed on 2 October 2021).

\subsection{Research Response to the Pandemic}

The ability of probiotics to inhibit the virus replication is more effective in the early onset of disease [14]. At present, there are eleven ongoing in vivo studies in this field whilst none of them have been completed (Table 2, Home-ClinicalTrials.gov, assessed on 31 December 2020); thus, the available evidence comes from the laboratory.

Research, at the time of the pandemic, poses a lot of challenges for academics. The design of the studies was dramatically rapid and, in some cases, with an impact on quality. The studies below enrolled a small number of participants, whilst heterogeneity was observed in measurements of the outcomes. Another possible drawback is the use of one probiotic strain in some interventions. Multispecies PB seems to be more effective compared to monostrain probiotics. When multispecies PB are combined, they act synergistically and can have a significantly positive effect. Their activity can also be stimulated through symbiosis among different strains [68]. 
Table 2. Ongoing in vivo studies evaluating probiotic treatment in patients with COVID-19 infection (ClinicalTrials.gov accessed on 31 December 2020).

\begin{tabular}{|c|c|c|c|c|c|c|c|c|}
\hline $\begin{array}{l}\text { Number of } \\
\text { Clinical Trial }\end{array}$ & Study Title & $\begin{array}{l}\text { Sample } \\
\text { Size }\end{array}$ & $\begin{array}{l}\text { Condition/ } \\
\text { Disease }\end{array}$ & Group & Interventions & Duration & Measurements & Outcomes \\
\hline 04621071 & $\begin{array}{c}\text { Efficacy of probiotics } \\
\text { in reducing duration } \\
\text { and symptoms of } \\
\text { COVID-19 }\end{array}$ & 84 & COVID-19 & $\begin{array}{c}\text { Control: } \\
\text { Placebo } \\
\text { Intervention: } \\
2 \text { probiotic strains }\end{array}$ & $\begin{array}{c}\text { Placebo: } \\
\text { (potato starch and } \\
\text { magnesium stearate) } \\
\text { Probiotic: } \\
\left(2 \text { strains } 10 \times 10^{9} \mathrm{CFU}\right.\end{array}$ & 25 days & $\begin{array}{c}\text { Questionnaires } \\
\text { (socio-demographic, } \\
\text { medical (weight, height, } \\
\text { general health, current } \\
\text { medication, symptoms), } \\
\text { food intake etc.). Optional } \\
\text { collection of saliva and } \\
\text { stool samples. }\end{array}$ & $\begin{array}{c}\text { Duration of } \\
\text { symptoms. Number } \\
\text { of days before } \\
\text { symptoms disappear. }\end{array}$ \\
\hline 04458519 & $\begin{array}{l}\text { Efficacy of intranasal } \\
\text { probiotic treatment to } \\
\text { reduce severity of } \\
\text { symptoms in } \\
\text { COVID-19 infection }\end{array}$ & 40 & COVID-19 & $\begin{array}{l}\text { Control: } \\
\text { Placebo } \\
\text { Intervention: } \\
\text { Probiotics }\end{array}$ & $\begin{array}{l}\text { Placebo: Saline solution } \\
\text { Probiotic: Lactococcus } \\
\text { lactis W136 } 2.4 \text { billion } \\
\text { CFU given intranasally }\end{array}$ & 4 weeks & $\begin{array}{l}\text { Visual Analogue Scale } \\
\text { (VAS) }\end{array}$ & $\begin{array}{c}\text { Change in severity of } \\
\text { COVID-19 infection. } \\
\text { Number of days with } \\
\text { any symptom of } \\
\text { COVID-19 infection } \geq \\
\text { to } 35 \text { as measured on } \\
\text { VAS at the 28-day } \\
\text { endpoint. }\end{array}$ \\
\hline 4366180 & $\begin{array}{l}\text { Evaluation of the } \\
\text { probiotic Lactobacillus } \\
\text { Coryniformis K8 on } \\
\text { COVID-19 prevention } \\
\text { in healthcare workers }\end{array}$ & 314 & COVID-19 & $\begin{array}{l}\text { Control: Placebo } \\
\text { Intervention: } \\
\text { Probiotics }\end{array}$ & $\begin{array}{c}\text { Placebo: maltodextrin } \\
\text { Probiotic: Lactobacillus } \\
\text { K8 per day }\left(3 \times 10^{9}\right. \\
\text { CFU/day) }\end{array}$ & 2 months & $\begin{array}{l}\text { SARS-CoV-2 detection by } \\
\text { PCR or antigen test }\end{array}$ & $\begin{array}{l}\text { Incidence of } \\
\text { SARS-CoV-2 infection } \\
\text { in healthcare workers }\end{array}$ \\
\hline 04666116 & $\begin{array}{c}\text { Changes in viral load } \\
\text { in COVID-19 after } \\
\text { probiotics }\end{array}$ & 96 & COVID-19 & $\begin{array}{c}\text { Control: } \\
\text { No dietary } \\
\text { administration } \\
\text { (probiotics). } \\
\text { Medication agreed } \\
\text { by the hospital } \\
\text { committee }\end{array}$ & $\begin{array}{l}\text { Dietary } \\
\text { supplementation with } \\
\text { strains from } \\
\text { Bifidobacterium longum, } \\
\text { Bifidobacterium animalis } \\
\text { subsp. Lactis and } \\
\text { Lactobacillus rhamnosus }\end{array}$ & 1 year & $\begin{array}{c}\text { SARS-CoV-2 detection by } \\
\text { PCR }\end{array}$ & $\begin{array}{l}\text { Viral load during the } \\
\text { period of admission }\end{array}$ \\
\hline
\end{tabular}


Table 2. Cont.

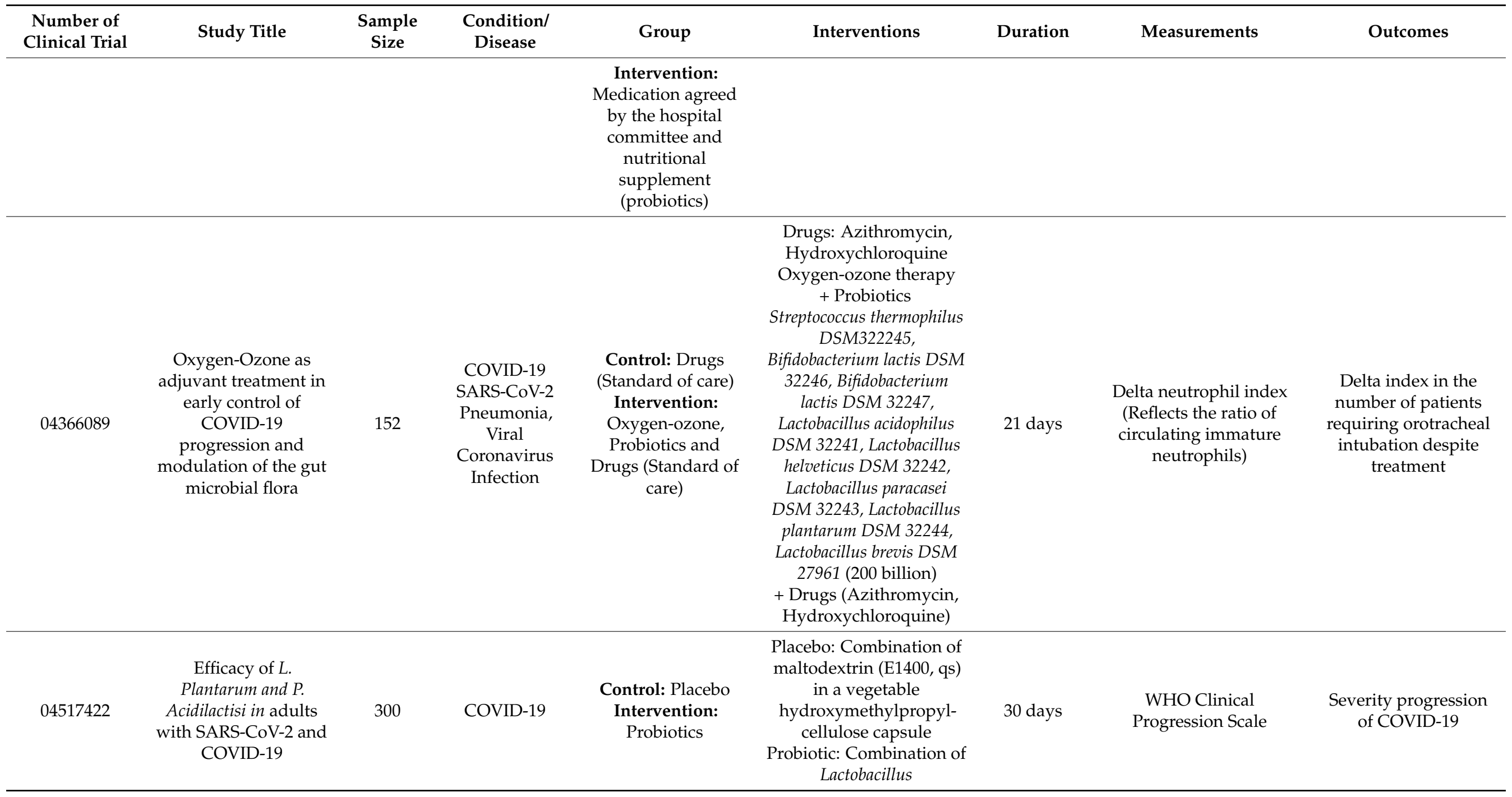


Table 2. Cont.

\begin{tabular}{|c|c|c|c|c|c|c|c|c|}
\hline $\begin{array}{l}\text { Number of } \\
\text { Clinical Trial }\end{array}$ & Study Title & $\begin{array}{l}\text { Sample } \\
\text { Size }\end{array}$ & $\begin{array}{l}\text { Condition/ } \\
\text { Disease }\end{array}$ & Group & Interventions & Duration & Measurements & Outcomes \\
\hline & & & & $\begin{array}{l}\text { Intervention: } \\
\text { Medication agreed } \\
\text { by the hospital } \\
\text { committee and } \\
\text { nutritional } \\
\text { supplement } \\
\text { (probiotics) }\end{array}$ & $\begin{array}{c}\text { plantarum CECT7481, } \\
\text { Lactobacillus plantarum } \\
\text { CECT } 7484, \text { Lactobacillus } \\
\text { plantarum CECT } 7485, \text { and } \\
\text { Pediococcus acidilactici } \\
\text { CECT } 7483\end{array}$ & & & \\
\hline
\end{tabular}


Table 2. Cont.

\begin{tabular}{|c|c|c|c|c|c|c|c|c|}
\hline $\begin{array}{l}\text { Number of } \\
\text { Clinical Trial }\end{array}$ & Study Title & $\begin{array}{l}\text { Sample } \\
\text { Size }\end{array}$ & $\begin{array}{l}\text { Condition/ } \\
\text { Disease }\end{array}$ & Group & Interventions & Duration & Measurements & Outcomes \\
\hline & & & & & $\begin{array}{l}\text { Lactobacillus plantarum } \\
\text { W62, Lactobacillus } \\
\text { rhamnosus W71 and } \\
\text { Lactobacillus salivarius W24 }\end{array}$ & & & \\
\hline 04399252 & $\begin{array}{l}\text { Effect of Lactobacillus } \\
\text { on the microbiome of } \\
\text { household contacts } \\
\text { exposed to COVID-19 }\end{array}$ & 1000 & $\begin{array}{l}\text { Microbiome/ } \\
\text { COVID-19 }\end{array}$ & $\begin{array}{l}\text { Control: Placebo } \\
\text { Intervention: } \\
\text { Probiotics }\end{array}$ & $\begin{array}{c}\text { Lactobaciltus rhamnosus } \\
\text { GG Placebo } \\
\text { Probiotic: Lactobacillus } \\
\text { rhamnosus GG }\end{array}$ & 28 days & Fecal samples & $\begin{array}{c}\text { Change in Shannon } \\
\text { Diversity Index }\end{array}$ \\
\hline
\end{tabular}




\section{Conclusions}

To conclude, PB may target SARS-CoV-2 in two different ways: by blocking virus invasion and replication through their metabolites, bacteriocins, and their ability to block ACE2 and by stimulating the immune response through NLRP3 regulation. While it is difficult to extrapolate the results from experimental studies with different strains and different types of samples in humans, in most of the above trials, PB were able to shield the host's immunity system. $\mathrm{PB}$ administration as a preventive method and therapeutic modality through the NLRP3 inflammasome manipulation should be tested as a safe and affordable solution.

Supplementary Materials: The following are available online at https://www.mdpi.com/article/10 .3390 /microorganisms9112376/s1; Table S1. In vivo and ex vivo studies in animals and cell culturesevaluating NLRP3 activation with probiotic administration.

Author Contributions: A.N.K. conceived the idea. K.D.T. supervised the work. M.D.N. developed the search strategy. K.D.S. contributed to the analysis and interpretation of the results. A.N.K. wrote the manuscript. A.N.K. and I.A.P. designed the figures. All authors contributed to the development of the selection criteria, strategy assessment, and data extraction criteria and discussed the results. All authors read, provided feedback, and approved the final manuscript. All authors have read and agreed to the published version of the manuscript.

Funding: This research received no external funding.

Institutional Review Board Statement: Not applicable.

Informed Consent Statement: Not applicable.

Data Availability Statement: Not applicable.

Conflicts of Interest: The authors declare no conflict of interest.

$\begin{array}{ll}\text { Abbreviations } \\ \text { ASC } & \text { Adaptor molecule apoptosis-associated speck-like protein } \\ \text { ACE2 } & \text { Angiotensin-Converting Enzyme 2 } \\ \text { BMECs } & \text { Bovine mammary epithelial cells } \\ \text { CARD } & \text { Caspase Activation and Recruitment Domain } \\ \text { COVID-19 } & \text { Coronavirus Disease 2019 } \\ \text { CE } & \text { Chronic Enteropathy } \\ \text { DAMPs } & \text { Damage-Associated Molecular Patterns } \\ \text { DC } & \text { Dendritic Cells } \\ \text { GRAS } & \text { Generally Regarded as Safe } \\ \text { GALT } & \text { Gut-Associated Lymphoid Tissue } \\ \text { GSDMD } & \text { Gasdermin D } \\ \text { HDPs } & \text { Host Defense Peptides } \\ \text { HFD } & \text { High Fat Diet } \\ \text { HK } & \text { Heat Killed } \\ \text { IECs } & \text { Intestinal Epithelial Cells } \\ \text { Ig } & \text { Immunoglobulin } \\ \text { IL } & \text { Interleukin } \\ \text { LAB } & \text { Lactic Acid Bacteria } \\ \text { LPS } & \text { Lipopolysaccharide } \\ \text { MA } & \text { Microbe-Derived Antioxidant } \\ \text { MAS } & \text { Macrophage Activation Syndrome } \\ \text { M } \Phi & \text { Macrophage } \\ \text { NF- } \text { B } & \text { Nuclear Factor-kappa B } \\ \text { NK } & \text { Natural killer cells } \\ \text { NLRP3 } & \text { NLR family pyrin domain containing 3 } \\ \text { NLRs } & \text { Nucleotide-Binding Oligomerization Domain-Like Receptors } \\ \text { PAMPs } & \text { Pathogen-Associated Molecular Patterns } \\ & \end{array}$




$\begin{array}{ll}\text { PB } & \text { Probiotic Bacteria } \\ \text { PPs } & \text { Peyer's patches } \\ \text { PRRs } & \text { Pattern Recognition Receptors } \\ \text { SCFA } & \text { Short-Chain Fatty Acids } \\ \text { TLR } & \text { Toll-like Receptors }\end{array}$

\section{References}

1. Llewellyn, A.; Foey, A. Probiotic Modulation of Innate Cell Pathogen Sensing and Signaling Events. Nutrients 2017, 9, 1156. [CrossRef] [PubMed]

2. Zmora, N.; Levy, M.; Pevsner-Fishcer, M.; Elinav, E. Inflammasomes and intestinal inflammation. Mucosal Immunol. 2017, 10, 865-883. [CrossRef]

3. Morais, A.H.A.; Maciel, B.L.L.; da Silva-Maia, J.K.; Passos, T.S. Can Probiotics and Diet Promote Beneficial Immune Modulation and Purine Control in Coronavirus Infection? Nutrients 2020, 12, 1737. [CrossRef]

4. $\quad$ Ding, L.; Gong, Y.; Yang, Z.; Zou, B.; Liu, X.; Zhang, B.; Li, J. Lactobacillus rhamnosus GG Ameliorates Liver Injury and Hypoxic Hepatitis in Rat Model of CLP-Induced Sepsis. Dig. Dis. Sci. 2019, 64, 2867-2877. [CrossRef] [PubMed]

5. Blaabjerg, S.; Artzi, D.M.; Aabenhus, R. Probiotics for the Prevention of Antibiotic-Associated Diarrhea in Outpatients-A Systematic Review and Meta-Analysis. Antibiotics 2017, 6, 21. [CrossRef] [PubMed]

6. Huang, R.; Hu, J. Positive Effect of Probiotics on Constipation in Children: A Systematic Review and Meta-Analysis of Six Randomized Controlled Trials. Front. Cell. Infect. Microbiol. 2017, 7, 153. [CrossRef]

7. Patel, R.M.; Underwood, M.A. Probiotics and necrotizing enterocolitis. Semin. Pediatric Surg. 2018, 27, 39-46. [CrossRef]

8. Zhang, G.-Q.; Hu, H.-J.; Liu, C.-Y.; Shakya, S.; Li, Z.-Y. Probiotics for Preventing Late-Onset Sepsis in Preterm Neonates: A PRISMA-Compliant Systematic Review and Meta-Analysis of Randomized Controlled Trials. Medicine 2016, 95, e2581. [CrossRef]

9. Wang, H.; Anvari, S.; Anagnostou, K. The Role of Probiotics in Preventing Allergic Disease. Children 2019, 6, 24. [CrossRef]

10. Nanavati, G.; Prasanth, T.; Kosala, M.; Bhandari, S.K.; Banotra, P. Effect of Probiotics and Prebiotics on Oral Health. Dent. J. Adv. Stud. 2021, 9, 1-6. [CrossRef]

11. Butera, A.; Gallo, S.; Maiorani, C.; Molino, D.; Chiesa, A.; Preda, C.; Esposito, F.; Scribante, A. Probiotic Alternative to Chlorhexidine in Periodontal Therapy: Evaluation of Clinical and Microbiological Parameters. Microorganisms 2021, 9, 69. [CrossRef]

12. Ermolenko, E.; Gromova, L.; Borschev, Y.; Voeikova, A.; Karaseva, A.; Ermolenko, K.; Gruzdkov, A.; Suvorov, A. Influence of Different Probiotic Lactic Acid Bacteria on Microbiota and Metabolism of Rats with Dysbiosis. Biosci. Microbiota Food Health 2013, 32, 41-49. [CrossRef] [PubMed]

13. Al Kassaa, I.; Hober, D.; Hamze, M.; Chihib, N.E.; Drider, D. Antiviral potential of lactic acid bacteria and their bacteriocins. Probiotics Antimicrob. Proteins 2014, 6, 177-185. Available online: http:/ /www.ncbi.nlm.nih.gov/pubmed/24880436 (accessed on 6 May 2021). [CrossRef] [PubMed]

14. Tiwari, S.K.; Dicks, L.M.T.; Popov, I.; Karaseva, A.; Ermakov, A.; Suvorov, A.; Tagg, J.R.; Weeks, R.; Chikindas, M.L. Probiotics at War Against Viruses: What Is Missing From the Picture? Front. Microbiol. 2020, 11, 1-21. [CrossRef]

15. Lescheid, D.W. Probiotics as regulators of inflammation: A review. Funct. Foods Health Dis. 2014, 4, 299. [CrossRef]

16. Zahid, A.; Li, B.; Kombe, A.J.K.; Jin, T.; Tao, J. Pharmacological Inhibitors of the NLRP3 Inflammasome. Front. Immunol. 2019, 10, 2538. [CrossRef] [PubMed]

17. Llorente, C.G.; Muñoz, S.; Gil, A. Role of Toll-like receptors in the development of immunotolerance mediated by probiotics. Proc. Nutr. Soc. 2010, 69, 381-389. [CrossRef] [PubMed]

18. Suresh, R.; Mosser, D.M. Pattern recognition receptors in innate immunity, host defense, and immunopathology. Adv. Physiol. Educ. 2013, 37, 284-291. [CrossRef]

19. Wang, L.; Hauenstein, A.V. The NLRP3 inflammasome: Mechanism of action, role in disease and therapies. Mol. Asp. Med. 2020, 76, 100889. [CrossRef]

20. Schroder, K.; Tschopp, J. The Inflammasomes. Cell 2010, 140, 821-832. [CrossRef]

21. Anwar, F.; Altayb, H.N.; Al-Abbasi, F.A.; Al-Malki, A.L.; Kamal, M.A.; Kumar, V. Antiviral effects of probiotic metabolites on COVID-19. J. Biomol. Struct. Dyn. 2020, 39, 4175-4184. [CrossRef]

22. Olaimat, A.N.; Aolymat, I.; Al-Holy, M.; Ayyash, M.; Abu Ghoush, M.; Al-Nabulsi, A.A.; Osaili, T.; Apostolopoulos, V.; Liu, S.-Q.; Shah, N.P. The potential application of probiotics and prebiotics for the prevention and treatment of COVID-19. npj Sci. Food 2020, 4, 17. [CrossRef]

23. Kelley, N.; Jeltema, D.; Duan, Y.; He, Y. The NLRP3 Inflammasome: An Overview of Mechanisms of Activation and Regulation. Int. J. Mol. Sci. 2019, 20, 3328. [CrossRef]

24. Wagatsuma, K.; Nakase, H. Contradictory Effects of NLRP3 Inflammasome Regulatory Mechanisms in Colitis. Int. J. Mol. Sci. 2020, 21, 8145. [CrossRef]

25. Russo, A.J.; Behl, B.; Banerjee, I.; Rathinam, V.A. Emerging Insights into Noncanonical Inflammasome Recognition of Microbes. J. Mol. Biol. 2018, 430, 207-216. [CrossRef] 
26. Carty, M.; Kearney, J.; Shanahan, K.A.; Hams, E.; Sugisawa, R.; Connolly, D.; Doran, C.G.; Muñoz-Wolf, N.; Gürtler, C.; Fitzgerald, K.; et al. Cell Survival and Cytokine Release after Inflammasome Activation Is Regulated by the Toll-IL-1R Protein SARM. Immunity 2019, 50, 1412-1424.e6. [CrossRef] [PubMed]

27. Evavold, C.; Ruan, J.; Tan, Y.; Xia, S.; Wu, H.; Kagan, J.C. The Pore-Forming Protein Gasdermin D Regulates Interleukin-1 Secretion from Living Macrophages. Immunity 2018, 48, 35-44.e6. [CrossRef] [PubMed]

28. Banerjee, I.; Behl, B.; Mendonca, M.; Shrivastava, G.; Russo, A.J.; Menoret, A.; Ghosh, A.; Vella, A.T.; Vanaja, S.K.; Sarkar, S.; et al. Gasdermin D Restrains Type I Interferon Response to Cytosolic DNA by Disrupting Ionic Homeostasis. Immunity 2018, 49, 413-426.e5. [CrossRef] [PubMed]

29. Schmitz, S.; Werling, D.; Allenspach, K. Effects of Ex-Vivo and In-Vivo Treatment with Probiotics on the Inflammasome in Dogs with Chronic Enteropathy. PLoS ONE 2015, 10, e0120779. [CrossRef]

30. Avolio, E.; Fazzari, G.; Zizza, M.; De Lorenzo, A.; Di Renzo, L.; Alò, R.; Facciolo, R.M.; Canonaco, M. Probiotics modify body weight together with anxiety states via pro-inflammatory factors in HFD-treated Syrian golden hamster. Behav. Brain Res. 2019, 356, 390-399. [CrossRef]

31. Teixeira, L.; Kling, D.; Lorca, G.; Gonzalez, C. Lactobacillus johnsonii N6.2 diminishes caspase-1 maturation in the gastrointestinal system of diabetes prone rats. Benef. Microbes 2018, 9, 527-539. [CrossRef]

32. Wu, Q.; Liu, M.-C.; Yang, J.; Wang, J.-F.; Zhu, Y.-H. Lactobacillus rhamnosus GR-1 Ameliorates Escherichia coli-Induced Inflammation and Cell Damage via Attenuation of ASC-Independent NLRP3 Inflammasome Activation. Appl. Environ. Microbiol. 2016, 82, 1173-1182. [CrossRef] [PubMed]

33. Xia, B.; Yu, J.; He, T.; Liu, X.; Su, J.; Wang, M.; Wang, J.; Zhu, Y. Lactobacillus johnsonii L531 ameliorates enteritis via elimination of damaged mitochondria and suppression of SQSTM1-dependent mitophagy in a Salmonella infantis model of piglet diarrhea. FASEB J. 2019, 34, 2821-2839. [CrossRef] [PubMed]

34. Loss, H.; Aschenbach, J.R.; Ebner, F.; Tedin, K.; Lodemann, U. Effects of a pathogenic ETEC strain and a probiotic Enterococcus faecium strain on the inflammasome response in porcine dendritic cells. Veter. Immunol. Immunopathol. 2018, $203,78-87$. [CrossRef]

35. Li, H.-H.; Li, Y.-P.; Zhu, Q.; Qiao, J.-Y.; Wang, W.-J. Dietary supplementation with Clostridium butyricum helps to improve the intestinal barrier function of weaned piglets challenged with enterotoxigenic Escherichia coli K88. J. Appl. Microbiol. 2018, 125, 964-975. [CrossRef] [PubMed]

36. Chung, I.-C.; Ouyang, C.-N.; Yuan, S.-N.; Lin, H.-C.; Huang, K.-Y.; Wu, P.-S.; Liu, C.-Y.; Tsai, K.-J.; Loi, L.-K.; Chen, Y.-J.; et al. Pretreatment with a Heat-Killed Probiotic Modulates the NLRP3 Inflammasome and Attenuates Colitis-Associated Colorectal Cancer in Mice. Nutrients 2019, 11, 516. [CrossRef]

37. Luo, Z.; Xu, X.; Zhao, S.; Sho, T.; Luo, W.; Zhang, J.; Xu, W.; Hon, K.; Xu, J. Inclusion of microbe-derived antioxidant during pregnancy and lactation attenuates high-fat diet-induced hepatic oxidative stress, lipid disorders, and NLRP3 inflammasome in mother rats and offspring. Food Nutr. Res. 2019, 63, 1-11. [CrossRef]

38. Tohno, M.; Shimosato, T.; Aso, H.; Kitazawa, H. Immunobiotic Lactobacillus strains augment NLRP3 expression in newborn and adult porcine gut-associated lymphoid tissues. Veter. Immunol. Immunopathol. 2011, 144, 410-416. [CrossRef]

39. Bai, L.; Kumar, S.; Verma, S.; Seshadri, S. Bacteriocin PJ4 from probiotic lactobacillus reduced adipokine and inflammasome in high fat diet induced obesity. 3 Biotech 2020, 10, 355. [CrossRef] [PubMed]

40. Fan, H.; Chen, Z.; Lin, R.; Liu, Y.; Wu, X.; Puthiyakunnon, S.; Wang, Y.; Zhu, B.; Zhang, Q.; Bai, Y.; et al. Bacteroides fragilis Strain ZY-312 Defense against Cronobacter sakazakii-Induced Necrotizing Enterocolitis In Vitro and in a Neonatal Rat Model. mSystems 2019, 4, e00305-19. [CrossRef]

41. Wu, X.; Pan, S.; Luo, W.; Shen, Z.; Meng, X.; Xiao, M.; Tan, B.; Nie, K.; Tong, T.; Wang, X. Roseburia intestinalis-derived flagellin ameliorates colitis by targeting miR-223-3p-mediated activation of NLRP3 inflammasome and pyroptosis. Mol. Med. Rep. 2020, 22, 2695-2704. [CrossRef] [PubMed]

42. Kern, M.; Aschenbach, J.R.; Tedin, K.; Pieper, R.; Loss, H.; Lodemann, U. Characterization of Inflammasome Components in Pig Intestine and Analysis of the Influence of Probiotic Enterococcus Faecium during an Escherichia Coli Challenge. Immunol. Investig. 2017, 46, 742-757. [CrossRef] [PubMed]

43. A Hajam, I.; Dar, P.; Shahnawaz, I.; Jaume, J.C.; Lee, J.H. Bacterial flagellin-A potent immunomodulatory agent. Exp. Mol. Med. 2017, 49, e373. [CrossRef]

44. Freeman, T.; Swartz, T.H. Targeting the NLRP3 Inflammasome in Severe COVID-19. Front. Immunol. 2020, 11, 1518. [CrossRef] [PubMed]

45. Xu, H.; Chitre, S.A.; Akinyemi, I.A.; Loeb, J.C.; Lednicky, J.A.; McIntosh, M.T.; McIntosh, S.B. SARS-CoV-2 viroporin triggers the NLRP3 inflammatory pathway. bioRxiv 2020, 357731. [CrossRef]

46. Kerget, B.; Kerget, F.; Aksakal, A.; Aşkın, S.; Sağlam, L.; Akgün, M. Evaluation of alpha defensin, IL-1 receptor antagonist, and IL-18 levels in COVID-19 patients with macrophage activation syndrome and acute respiratory distress syndrome. J. Med. Virol. 2020, 93, 2090-2098. [CrossRef] [PubMed]

47. Soltani, S.; Hammami, R.; Cotter, P.D.; Rebuffat, S.; Ben Said, L.; Gaudreau, H.; Bédard, F.; Biron, E.; Drider, D.; Fliss, I. Bacteriocins as a new generation of antimicrobials: Toxicity aspects and regulations. FEMS Microbiol. Rev. 2021, 45, fuaa039. [CrossRef] [PubMed] 
48. Shah, A. Novel Coronavirus-Induced NLRP3 Inflammasome Activation: A Potential Drug Target in the Treatment of COVID-19. Front. Immunol. 2020, 11, 1021. [CrossRef]

49. Effenberger, M.; Grabherr, F.; Mayr, L.; Schwaerzler, J.; Nairz, M.; Seifert, M.; Hilbe, R.; Seiwald, S.; Scholl-Buergi, S.; Fritsche, G.; et al. Faecal calprotectin indicates intestinal inflammation in COVID-19. Gut 2020, 69, 1543-1544. [CrossRef]

50. Zhang, H.; Kang, Z.; Gong, H.; Xu, D.; Wang, J.; Li, Z.; Li, Z.; Cui, X.; Xiao, J.; Zhan, J.; et al. Digestive system is a potential route of COVID-19: An analysis of single-cell coexpression pattern of key proteins in viral entry process. Gut 2020, 69, 1010-1018. [CrossRef]

51. Singh, A.K.; Singh, A.; Shaikh, A.; Singh, R.; Misra, A. Chloroquine and hydroxychloroquine in the treatment of COVID-19 with or without diabetes: A systematic search and a narrative review with a special reference to India and other developing countries. Diabetes Metab. Syndr. Clin. Res. Rev. 2020, 14, 241-246. [CrossRef]

52. Villena, J.; Kitazawa, H. Editorial: Immunobiotics-Interactions of Beneficial Microbes with the Immune System. Front. Immunol. 2017, 8, 1580. [CrossRef] [PubMed]

53. Mortaz, E.; Adcock, I.; Folkerts, G.; Barnes, P.J.; Vos, A.P.; Garssen, J. Probiotics in the Management of Lung Diseases. Mediat. Inflamm. 2013, 2013, 751068. [CrossRef] [PubMed]

54. Stavropoulou, E.; Bezirtzoglou, E. Probiotics in Medicine: A Long Debate. Front. Immunol. 2020, 11, 2192. [CrossRef] [PubMed]

55. Serkedjieva, J.; Danova, S.; Ivanova, I. Antiinfluenza Virus Activity of a Bacteriocin Produced by Lactobacillus delbrueckii. Appl. Biochem. Biotechnol. 2000, 88, 285-298. [CrossRef]

56. Wachsman, M.B.; Castilla, V.; De Ruiz Holgado, A.P.; De Torres, R.A.; Sesma, F.; Coto, C.E. Enterocin CRL35 inhibits late stages of HSV-1 and HSV-2 replication in vitro. Antivir. Res. 2003, 58, 17-24. [CrossRef]

57. Salman, J.A.-S.; Mahmood, N.N.; Abdulsattar, B.O.; Abid, H.A. The Effectiveness of Probiotics against Viral Infections: A Rapid Review with Focus on SARS-CoV-2 Infection. Open Access Maced. J. Med. Sci. 2020, 8, 496-508. [CrossRef]

58. Forman, H.J. Hydrogen Peroxide: The Good, The Bad, and The Ugly. In Oxidants in Biology; Springer: Dordrecht, The Netherlands, 2008; pp. 1-17.

59. De Brito, L.P.; da Silva, J.N., Jr.; de Barros, P.D.S.; da Silva, E.C.; de Calaça, P.R.; Soares, M.T.C.V.; Porto, A.L.F. Can postbiotics show antiviral effects against SARS-CoV-2? Res. Soc. Dev. 2021, 10, e17259. [CrossRef]

60. American Veterinary Medical Association. SARS-CoV-2 in Animals 2020. Available online: https://www.avma.org/resourcestools/animal-health-and-welfare/covid-19/sars-cov-2-animals-including-pets (accessed on 6 May 2021).

61. Fuglsang, A.; Rattray, F.P.; Nilsson, D.; Nyborg, N.C. Lactic acid bacteria: Inhibition of angiotensin converting enzyme in vitro and in vivo. Antonie Van Leeuwenhoek 2003, 83, 27-34. [CrossRef]

62. Wu, D.; Yang, X.O. TH17 responses in cytokine storm of COVID-19: An emerging target of JAK2 inhibitor Fedratinib. J. Microbiol. Immunol. Infect. 2020, 53, 368-370. [CrossRef]

63. Harrison, A.G.; Lin, T.; Wang, P. Mechanisms of SARS-CoV-2 Transmission and Pathogenesis. Trends Immunol. 2020, 41, 1100-1115. [CrossRef] [PubMed]

64. Bermudez-Brito, M.; Plaza-Díaz, J.; Muñoz-Quezada, S.; Gómez-Llorente, C.; Gil, A. Probiotic mechanisms of action. Ann. Nutr. Metab. 2012, 61, 160-174. [CrossRef]

65. Gohil, K.; Samson, R.; Dastager, S.; Dharne, M. Probiotics in the prophylaxis of COVID-19: Something is better than nothing. 3 Biotech 2021, 11, 1. [CrossRef] [PubMed]

66. Chen, Y.; Liu, W.; Xue, J.; Yang, J.; Chen, X.; Shao, Y.; Kwok, L.-Y.; Bilige, M.; Mang, L.; Zhang, H. Angiotensin-converting enzyme inhibitory activity of Lactobacillus helveticus strains from traditional fermented dairy foods and antihypertensive effect of fermented milk of strain H9. J. Dairy Sci. 2014, 97, 6680-6692. [CrossRef]

67. Gonzalez-Gonzalez, C.; Gibson, T.; Jauregi, P. Novel probiotic-fermented milk with angiotensin I-converting enzyme inhibitory peptides produced by Bifidobacterium bifidum MF 20/5. Int. J. Food Microbiol. 2013, 167, 131-137. [CrossRef] [PubMed]

68. Timmerman, H.; Koning, C.; Mulder, L.; Rombouts, F.; Beynen, A. Monostrain, multistrain and multispecies probiotics-A comparison of functionality and efficacy. Int. J. Food Microbiol. 2004, 96, 219-233. [CrossRef] 